\title{
Behind the Mask: Hybrid Identity Work of Indian Women Managers in Corporate South Africa
}

\author{
Nasima M. H. Carrim \\ Human Resource Management Department \\ Faculty of Economic and Management Sciences \\ University of Pretoria, Pretoria, South Africa \\ nasima.carrim@up.ac.za
}

\begin{abstract}
There is a dearth of research on how women managers engage in hybrid identity work during their career transitions, and the aim of this study was to fill this gap. Interviews were conducted with 13 Indian women managers in senior and top managerial positions, and the data obtained were analysed using thematic analysis. The narratives indicate that previously disadvantaged groups (Indian women in this case) are caught between subscribing to cultural values and concurrently conforming to organisational norms. Participants' answers to the question: "Who am I as an Indian female manager?" reveal that during their career ascendency these women engage in a tremendous amount of hybrid identity work and rework related to their self-concept of being an "ideal" Indian female and simultaneously being a "perfect" manager. Nevertheless, in their career transitions to managerial positions, these women are selective in the hybrid identity work they engage in.
\end{abstract}

\section{Keywords}

hybridity - identity work - career transition - racio-ethnic identity - professional identity

\section{Introduction}

The objective of the current research was to ascertain how Indian women managers engage in hybrid identity work to reach a sense of coherence in the 
process of negotiating their gender and racio-ethnic identities and in the process accommodating and resisting the strictures of a white, male-dominated organisational culture within a particular socio-historical context. Most studies relating to minorities in organisations do not focus on hybrid identity work. In the field of psychology, Helms (1990) has delineated the processes of racial identity relating to racial minorities, suggesting that these minorities have singular identities. The idea of hybridity and the concept of people having multiple identities raise questions as to how people negotiate and deal with these identities. Cieslik and Verkuyten (2006) indicate that people tend to retain their cultural values and adopt new ones in their interactions with others. Multiple identities can be reconciled but they cause conflict and tension as they also need to be reconciled and accommodated. The term hybridity, which was coined in the 1980 s, is used to illustrate cultural phenomena and identities, in other words, the "different lifestyles, behaviours, practices, and orientations that result in multiple identities which are blended, combined and mixed" (Cieslik and Verkuyten 2006: 78). Easthope (2009) points out that the word hybridity is used to describe people of mixed race, and when theorists speak about the notion of people being between positions they refer to the concept of in-betweenness. Hybridity can also refer to the integration of conflicting messages relating to different cultures, in that way forming new ways of doing things but retaining the contradictory culture as a visible and powerful force (Brettell and Nibbs 2009). Old, traditional values are abandoned and new identities are assimilated. Hybridity takes place when ethnic minorities fuse cultural, racial and diverse lifestyles to form new identities.

One participant in the current study verbalised the conflict an in-between position can give rise to:

In order to fit in with male managers, you tend to become more assertive and learn to handle conflict constructively. However, you struggle to advance in the organisation because you cannot bridge cultural and organisational values and norms, as the Indian culture remains a major part of you. You're not one of the boys and that is where we struggle because we're caught in this chasm of we're not very "male", neither are we very "Western female" and we're caught in this trap. You can't make it in the male domain because you're not into drinking and golf. So, there is always conflict between who you are as an Indian female and who you are as a professional working in a Western corporate culture.

SHARMILA, Business Application Manager 
The focus of the concept of identity work is on the processes that result in identity development at an individual level (Andersson 2010) and also on the comprehension of how people identify with their jobs and the workplace (Sveningsson and Alvesson 2003). Central to this understanding is how individuals "form, repair, maintain, strengthen or revise constructions that result in their achievement of a sense of coherence and distinctiveness" (Sveningsson and Alvesson 2003: 1165).

Research related to managerial identity work has become popular in recent years (Andersson 2010; Sturdy et al. 2006; Watson 2008, 2009) and studies have focused on managerial control (Kärreman and Alvesson 2004), identity regulation (Alvesson and Willmott 2002) and the role of gurus in influencing managerial identities (Clark and Salaman 1998). A connection has also been established between identity work and managers' career transitions (Andersson 2010; Blenkinsopp and Stalker 2004; Ibarra and Barbulescu 2010) and their personal and social identities (Beech 2008; Watson 2008).

Examining individuals' promotions to management positions and how they engage in identity work has also been studied widely (Ashforth 2001; Ibarra 2005). However, research relating to identity negotiation has overwhelmingly focused on males and females in Western contexts (Andersson 2010; Sveningsson and Alvesson 2003; Watson 2008).

Research on managerial identity work has not accounted for the complexities that arise when individuals from a racio-ethnic group whose culture differs from that of the mainstream organisational culture, enter the workplace. There is a dearth of information in the literature on the extent to which minority managers integrate into the majority organisational culture, relinquish their own ethnic values and beliefs and engage in hybrid identity work. Much of the extant research on hybrid identity work that racio-ethnic "others" engage in, focuses on non-managerial employees (Das 2007; McKinley 2008; Van Laer and Janssens 2008). In addition, few studies focus on gender and how hybrid identities are constructed and negotiated (Darling-Wolf 2008). The current study fills the identified gaps by focusing on Indian women managers and asking the central question: To what extent do racio-ethnic minority women engage in hybrid identity work in their upward career mobility?

A greater insight into the extent to which Indian minority women engage in identity work and form hybrid identities is required for several reasons. Firstly, little is known of the extent to which Indians on the African continent have assimilated Western values relating to women's economic liberation, leadership roles and acceptance of their managerial status. Secondly, there is a dearth of knowledge on the degree to which these women are willing to give up their 
cultural values and beliefs and integrate organisational values. Thirdly, little is known about the extent to which the family and community encourage professional Indian women to engage in hybrid identity work.

Through the life stories of Indian women managers in South Africa, this study demonstrates how the hybrid identity work related to becoming a manager becomes complicated when gender and racio-ethnic identities shape and reshape women's self-concepts and professional identities as managers. It is argued that the hybrid identity work engaged in by women in corporate South Africa to formulate their managerial identities is not just a matter of answering the question: "Who am I as a manager?" Given the continuing influence of the historical socio-political position of Indians in apartheid and post-apartheid South Africa, the question is much more complex. The women's stories illustrate how they continually engage in the negotiation and renegotiation of their gender and racio-ethnic identities to form workable managerial identities. Such an approach is imperative, given the increasingly diverse identities in managerial positions in organisations worldwide (Giscombe and Mattis 2002).

The researcher used thematic analysis and the hybrid identity theory as a framework to analyse the life stories of the 13 senior Indian women managers who participated in the study. In narrating their experiences, they revealed the complex hybrid identity work they engaged in to construct a coherent managerial identity while negotiating the interface between their gender and racio-ethnic identities and meeting the need to accommodate and resist the strictures of a white, male-dominated organisational culture within a particular socio-historical context.

Following a discussion of the relevant theoretical perspective and the South African context, the attention turns to a description of the research methodology followed and the participating women's hybrid identity work relating to engaging in multiple social identities within an oppressive political system. After a discussion of the findings, concluding remarks are made.

\section{Literature Overview}

Existing literature on identity work and hybrid identity work served to expand and provide a framework for the current research on understanding how cultural identities are negotiated and formulated, resulting in mixed identities. The broader theory relating to identity work and the concept of hybrid identity work provided a holistic view of the forces of suppression and privilege within a broader social context and Indian women managers' concomitant struggles, 
thus negating the myopic view of the individual having only a managerial identity.

Under the umbrella of the social identity theory, the focus is on identity work to indicate how participants negotiate their identities and on hybrid identities to indicate how they formulate new "mixed" identities.

\section{Social Identity Theory}

The concept of social identity was formulated by Henri Tajfel who defined it as "that part of an individual's self-concept which derives from his knowledge of his membership of a social group ... together with the value and emotional significance attached to that membership" (Tajfel, 1972: 292). The basic premise of social identity theory is that the social group one belongs to (in terms of nationality, gender, ethnicity) defines who one is and forms part of one's selfconcept (Hogg, Terry, and White 1995).

The concept of racio-ethnic identity (as a form of social identity) was formulated by Cox (1990), according to whom individuals from different race groups are biologically and culturally distinct. Subsequently, researchers have included the concept of racio-ethnicity in their studies. For example, Fearfull and Kamenou (2006) conducted interviews with 26 female participants from different racio-ethnic groups (nine Afro-Caribbeans, 11 Pakistanis, two Indians, two South Asians and one African) in three organisations in the United Kingdom to study the discrimination these women experienced in their workplaces. They found that racio-ethnic minority women were not accepted and had limited opportunities to progress in organisations, despite non-discriminatory legislation being in place. Antecol and Bedard (2002) compared the earnings of Mexican and black women in the United States to those of white women, and found that as a result of their lower racio-ethnic status and educational levels, Mexican and black women earned less than white women.

Gender is another salient social identity that pervades social interactions and is an intrinsic part of social institutions (Mehrotra and Calasanti 2010). A woman's sense of self develops based on her view of what it means to be a woman in society and the success with which she connects with others (Carrim 2012). Gender becomes especially salient in management roles in male-dominated industries. The competency and legitimacy of women who behave agentically and assertively in management posts are questioned and met with hostility and resistance (Stoker, Van der Velde, and Lammers 2012). For example, Ford (2006) conducted a study on 25 male and female middle managers in a metropolitan council district in the United Kingdom and found that feminine gender identities were constantly challenged within this environment and that 
female managers tended to adopt contradictory and fragmented male managerial identities if they wanted to be regarded as effective managers. Dennis and Kunkel (2004) conducted a study on $220 \mathrm{CEO}$, which revealed that gender identity was important to perceptions of similarities and differences between male and female executives.

Social identity theory stresses that, depending on the relations between groups and the social context, in-group members display varying levels of stereotypical behaviour such as favouring the self and their own groups and discriminating against the out-group (Hogg, Terry, and White 1995). In the apartheid era, the state deliberately attempted to give power to whites at all levels in society and, to this end, instituted macro policies to place blacks in an unfavourable position. However, social identity theory does not account for the discriminatory role of the state as a social group in granting varying levels of power to different groups. This study addresses this gap by focusing on the apartheid system and the role it played in placing white males in powerful positions in organisations and creating the situation of their being examples to be emulated by others (from other race groups) in order to be regarded as successful managers.

\section{Identity Work}

Kreiner, Hollensbe, and Sheep (2006: 1032) assert that individuals who enter a workplace ask "Who am I?" in an environment of "This is who we are" messages. Individuals, their social contexts and their relationships are dynamic, and when they respond dynamically to these dynamics, identity work takes place.

Identity work is an intricate phenomenon: individuals' identity claims can be ignored, rejected, accepted or not recognised. Identity work, therefore, requires interaction with others, as the intensity of identity assertions depends on how others respond to them (Jenkins 1996) and what they tolerate (Ibarra and Petriglieri 2010). Whereas some individuals accept certain norms of a social category, others resist them and yet others may pretend to conform but reject them in subtle ways (Beech 2008).

Research on identity work has gained currency in organisational studies as a means of understanding how people construct and negotiate their identities, which are often unclear in multifaceted situations in the workplace (Atewologun and Singh 2010). Much research has been conducted on managerial identity work (Alvesson and Willmott 2002; Andersson 2010; Sveningsson and Alvesson 2003); however, scholars have focused on managers in organisational settings and the identity struggles they experience in their roles. Watson (2008), on the other hand, postulates that an analysis of narratives becomes more powerful when it is acknowledged that apart from the shaping of internal 
identities there are forces that act on managers' external identities. In examining both the external and internal aspects of the narrative of a white male manager, Watson (2008) focuses on the man's family, school experiences and early career encounters that have shaped and reshaped his managerial identity. However, Watson (2008) does not take into account the socio-historical elements that may have shaped the manager's current identity work. In order to fill this gap, this study focused on both the racio-ethnic and socio-historical context that impacted on the identity work of the participants.

One of the issues in organisations is the increasingly diverse managerial identities owing to the increasing number of women in management. The notion of management being a masculine domain and managerial identities being relatively stable has been toppled (Alvesson and Willmott 2002). These authors state that many scholars have called for the de-masculinisation of management and the inclusion of feminine identities. Nevertheless, most studies on managerial identity work are based on male managers. A case in point is the longitudinal study of Beech (2008) that focused on the tensions and enabling factors in identity work based on the narrative of a male manager. In studies that include female managers, no distinction is drawn between how male and female managers engage in managerial identity work. Andersson (2010) studied the process of becoming a manager and the concomitant struggles that both males and females experienced in relation to their identities. However, despite substantial research evidence that women experience challenges in a male-dominated profession, he did not focus on the different experiences of the males and females in becoming managers in the particular organisation in question. Instead, the study assumed that the identity work of becoming a manager was the same for male and female managers (Andersson 2010).

The majority of studies on managerial identity work are conducted from a white male and white female perspective. Sometimes the races of the participating women managers are not explicitly identified, but in most cases the studies are based on white females' perspectives. In their study on understanding identity construction in a managerial context, Sveningsson and Alvesson (2003) focused on the narratives of a female manager without disclosing her race. They pointed out that the female manager they had interviewed had not referred to her gender in her narratives about constructing a managerial identity. However, the researchers implicitly alluded to the participant being a white female, and they identified the need to investigate gender and ethnicity in research on identity construction and negotiation.

Furthermore, identity studies on women are mainly not based on the African continent. For example, Ezzel (2009) studied a woman's rugby team in the United States and found that the players did not fight against homophobic 
and sexist stigmas but distanced themselves from other subordinate groups, reinforced their own devalued identities and identified with dominant players and bolstered their image. The players' identity work supported heterosexism and gender inequality. One of the rare studies using non-white participants is the one done by Essers and Benschop (2009) who researched the ways 20 Moroccan and Turkish business women in the Netherlands negotiated their ethnic, gender and entrepreneurial identities in relation to their Muslim identities. The results of the study indicated that these women opposed the traditional values their culture imposed on women by becoming entrepreneurs and negotiating in that context how to deal with male clients and how to operate in their communities where the norm was for women to be homemakers and child carers.

Considering the sparse research conducted on non-white women, this study aimed to fill this gap by focusing on Indian women managers who did not form part of mainstream white (male and female) managerial teams.

\section{Hybrid Identity Work}

The concept hybridity has different meanings in different disciplines. Within organisational studies, hybridity refers to group cultures that emerge in transnational teams (Early and Mosakowski 2000). The term hybrid is defined in the Merriam-Webster dictionary (Merriam-Webster n.d.) as referring to a person who is a blend of two distinct cultures or traditions, or to something that has a heterogeneous composition or origin.

Bhabha (1994) introduced the concept of hybridity in his studies on postcolonialism in which he depicted Indian society as being socialised to mimic British colonisers as closely as possible in terms of dress and the use of the English language. The aim was to ensure that Indians closely resembled the British in terms of social etiquette; however, the British did not accept them as equals. In the current study the researcher used this theory to expound the extent to which Indian women "mimicked" white male managers as they rose to senior and top managerial positions.

Some criticism has been levelled at Bhabha's (1994) conceptualisation of the term hybrid identities. Firstly, Bhabha (1994) assumes that there is a distinct cultural divide between the coloniser and the colonised (Benton and Muth 2000), an assumption that negates the fact that people from a particular class and ethnic background can be driven by different motives and can react differently in a given situation (Fitzgerald 2007). Secondly, feminists criticise Bhabha's (1994) notion of hybridity as it does not account for gender and the role of women in power relationships. This study aimed to fill these gaps, in the first place by providing the participants' motives for engaging in hybrid 
identity work during their career ascendancy and in the second place by selecting Indian women in powerful positions to participate in this study.

Research related to hybrid identity work in organisations is limited but a few examples can be mentioned. In a study that Das (2007) conducted in India it was found that call centre agents adopted a different cultural identity when communicating with customers to facilitate smooth interaction. The study addressed the extent to which these agents mimicked their Western counterparts but did not explicitly state the extent to which they internalised such behaviour in their social interactions with family and friends. McKinley (2008) explored how Maori women scientists in New Zealand experienced hybrid identities through science education but did not focus on career transitions. Bazylevych (2010) explored the meaning of prestige in the socialist and post-socialist eras and how female doctors' professional identities became hybrid in the Ukrainian context. Van Laer and Janssens (2008) investigated the workplace experiences of second-generation Turkish professionals in Belgium and their equaltion of their identities with hybrid identities. LukFong (2010) conducted a study on the ways that women teachers in China negotiated their hybrid identities as professionals and their roles as wives and mothers.

The studies mentioned above dealt with the engagement in hybrid identity work of professionals already established in their careers. A gap filled by the current study is to focus on how Indian women engage in hybrid identity work during career transitions in their journey toward becoming managers.

\section{The South African Context}

The different historical, political and social contexts in countries affect the type of identity work women engage in as they enter male-dominated organisations. Apartheid was a racial classification system in South Africa that separated four different race groups: whites (Afrikaners and British), Africans, Asians and coloureds. This division along political, economic and social lines was enforced through legislation (Ramsay 2007) and dominated all areas of people's lives, from education to employment (Moosa 2004).

The apartheid system was based on patriarchy and sexism not only in the macro environment but also in the micro environment of homes and communities. All women were relegated to a status secondary to men and were regarded as minors without decision-making and leadership powers in the private domain (Mathur-Helm 2004). The patriarchal system spilled over into the workplace: women of all races faced inequity, but black women were even 
more discriminated against than white women. White women had access to better-paid, higher-status jobs such as administrative positions (Carrim 2012), whereas Indian, coloured and African women were concentrated in lowerpaying, unskilled, menial jobs (Mathur-Helm 2005). The latter group was also denied the same educational opportunities as white women (Naidoo and Kongolo 2004). Indian women faced triple discrimination (class, gender and race) as a result of the apartheid system.

The democratic elections in 1994 brought an end to apartheid, one of the most oppressive systems in modern history (Booysen 2007). The said author observes that although blacks have since gained political power, economic power still belongs to whites. In addition, a race and gender hierarchy still exists in the workplace: white males dominate top and senior managerial positions, especially in the private sector.

Prior to 1994, racial and gender discrimination in South Africa caused major inequalities in the labour market (Greeff and Nel 2003). The Employment Equity Act was passed by Parliament in 1998 to address the imbalances of work opportunities for blacks (including coloureds, Africans and Indians), women and persons with disabilities (Naidoo and Kongolo 2004).

\section{Method}

\section{Sampling}

To gain an in-depth understanding of how the participants in this study engaged in identity work related to their gender, racio-ethnic and professional identities, a qualitative, interpretivist approach was used to allow the women to share their life experiences (Ritchie and Lewis 2003). Thirteen Indian women in senior and top managerial positions from various South African organisations were interviewed. The purpose was to gain access to the perspectives of the first cohort of Indian women to enter senior managerial positions in corporate South Africa. Participants were selected through a combination of purposive and snowball sampling, and they were all provided with pseudonyms to maintain confidentiality. The ages of the women ranged from 35 to 46 years, they occupied managerial positions ranging from project manager to legal director, and the majority of them held postgraduate degrees. All the women were born and raised during the apartheid era and were confined to demarcated Indian townships where they were educated in designated Indian schools. They were all educated in designated Indian universities, except two who were granted special permission by the government to attend white universities. At the time of the interviews, nine of the women were married, one was 
divorced and three were single. All the women were from middle-class business backgrounds. The women's work experience averaged a period of 10 years, and the minimum number of years in senior management positions was three.

\section{Interview Procedure}

In-depth, semi-structured life-story interviews were conducted with the participants. Based on the participants' preferences, interviews were conducted in coffee shops, homes and offices. The semi-structured interview protocol was to probe the workplace experiences of the women with specific focus on the socio-historical-political context, racio-ethnicity, gender and the professional identity work the women had engaged in. The interview questions required the women to reflect on the experiences they had during the early stages of their careers, with specific focus on how the apartheid system had influenced their identities. Examples of questions were:

APPENDIX 1 Sample interview questions

"Tell me about how you charted your career path on your journey to management?"

"What were managers' expectations of you in a higher management position?" "What type of support did you receive from male and female colleagues?"

"Were there differences in the type of support you received compared to other colleagues?"

The one-on-one interviews lasted two hours each and were audio-taped so as to facilitate retrieval and review of information and sustain the validity of the study. Two follow-up interviews of two hours each were conducted with each participant to probe deeper and clarify themes that had been extracted from the data obtained in the first round of interviews. Further follow-up interviews were not conducted as data saturation had been reached.

\section{Data Analysis}

Interviews were transcribed verbatim after each interview session. In extracting the themes, the researcher was guided by the study's research questions. The researcher was aware that the participants could not be divorced from the macro environment that influenced their careers and, therefore, cognisance was taken of the socio-historical-political context in analysing data (Charmaz 2006). 
An iterative approach to data analysis was followed in that the researcher moved back and forth between the data, relevant theory and interpretation (Ladge, Clair, and Greenberg 2012). Analysis was conducted through inductively formulating the codes that had emerged. A second independent researcher, who was given a subset of the interviews to code, indicated his agreement with the coding.

The Atlas.ti software program was used to manage, analyse and code the large amount of unstructured data collected from the women's life stories (Wickham and Woods 2005). In analysing the data, thematic analysis was used to extract themes relating to hybrid identity work that had emerged from the interviews (Charmaz 2006). Through this approach the researcher gained a deeper understanding of and insight into the hybrid identity work of the women relating to their racio-ethnicity and gender identities in their particular socio-historical and political context (Strauss and Corbin 1998). Thematic analysis was a useful and flexible research tool to obtain rich and detailed yet complex accounts of how the participants engaged in hybrid identity work (Strauss and Corbin 1998).

The current paper is based on the analysis of three codes, namely, "Indian culture", "Managerial identity" and "Organisational culture". From these codes three overarching themes were extracted, namely, "integrating managerial identities", "normality at home" and "resisting corporate culture". The study results that are presented below in terms of the three themes reveal the tensions these women experienced in forming hybrid identities and reconciling their self-concepts with the expectations of their organisations, homes and communities.

\section{Results}

\section{Integrating Managerial Identities}

The women were all raised in insulated Indian townships where cultural beliefs were strongly adhered to. The participants did not leave the familiarity of these environments when they reached adulthood as they preferred living amongst family and friends. As a result, when the women entered the workplace, they experienced a culture shock as workplace expectations in terms of career advancement were in conflict with their cultural values and beliefs. They were not forewarned that organisational culture was different and had no knowledge about this as Indian men and women had been denied positions in corporate South Africa owing to the Job Reservation Act of 1926 (Daniel, Habib, and Southall 2003). In addition, the women who participated in this study were, in most cases, the only Indian women in their organisations. Rani, 
a human resource director, commented on feeling alienated when she first entered the workplace:

I was the first member of my family to enter the corporate environment. I had no male or female family or friends I could talk to about my workplace experiences and how to resolve issues. In those initial years of my career I really felt lost and alone as there were no Indian women in my workplace. They only started recruiting women a few years after I joined the company.

At first all these women resisted changing their cultural values as the Indian culture prescribes that respectable Indian women should not take the initiative in certain matters, for instance, asking a manager for a bonus or to serve on a workplace committee. When they were growing up, their parents encouraged them to accept their circumstances in life. The participants realised that if they did not take the initiative in the workplace (e.g. by asking to be part of projects) and stand up for their rights, they would not advance in their careers. Initially it was difficult to adapt to organisational prescripts about the behaviour of managers as these completely contradicted Indian cultural prescripts about the behaviour of respectable women. However, once the women realised these were workplace expectations, they started integrating managerial personas into their self-concepts. Nevertheless, they experienced tremendous inner conflict as they felt that their behaviour was not authentic and that they were negating their cultural beliefs. In time they accepted that in order to advance in their careers they would have to negate certain cultural values and integrate the corporate norms that managers were expected to adhere to. Karina, a marketing manager, highlighted how difficult it was to ask to participate in workplace assignments but how she learned to deal with organisational values that conflicted with her cultural values:

As Indians we are taught not to ask for what we want. We assume people will automatically include us in important decisions and tasks. In the workplace it is very different as we have to assert ourselves and ask to be included in assignments. I even had to ask my manager why I was not getting a performance bonus and this I did after working for the company for three years. When I asked him why the others were getting performance bonuses and I got nothing although I worked so hard. His answer to me was that you need to learn to ask for what you want.

All the participants pointed out that they, being Indian women, had been harassed by Indian males when they had first entered the workplace. Under 
the encouragement of white male managers, these women learned to assert themselves and stand up to Indian males although this was against their cultural beliefs. Additionally, the majority of the participants learned to express their opinions and even to contradict older Indian males - behaviour that is frowned upon in the Indian culture as the young are expected to respect their elders. The women indicated that they had to undergo a mind-set change and make a concerted effort to regard Indian men as their equals in the workplace because in their homes and communities women were regarded as subordinate to males.

The women remarked that they avoided talking to Indian males at corporate social gatherings so as to protect their respectability because the Indian culture prescribed sex segregation. However, in their dealings with Indian male colleagues, they maintained a professional relationship and learned to handle conflict in a constructive manner. According to the respondents, Indian men in the workplace expected Indian female colleagues to be as subservient as they were in the home and the community. However, the women felt that they had to stand up to these males regardless of how difficult it was, even if it went against their belief system. The women learned to assert themselves and handle conflict situations with men and women from other race groups regardless of their ages. Mahima referred to the reservations the women had about their behaviour towards Indian male colleagues and how they were eventually able to overcome these:

When it came to addressing Indian males in the workplace, I would feel shy. The reason being, that Indian females are usually in the background when it comes to social gatherings and the men give the speeches and are in the forefront. This type of mentality makes it difficult to be out there. Indian males give Indian women a difficult time in the workplace as they believe that we should be at home and not in management.... Unfortunately, the workplace calls for different behaviours to what we are accustomed to as Indian women and if we want to get ahead in our careers we need to leave some part of our cultures behind which, incidentally, I did although it was difficult. I felt guilty for not being true to my cultural values but then I would not be a manager had I stuck to my culture.

\section{Resisting Corporate Culture}

All the participants refused to use networking to advance their careers. They believed in their fathers' formula that hard work resulted in business success. Although they realised that upward career mobility after reaching senior management level depended a great deal on social networking with male managers, 
they refused to join the "old boys" network or start to play golf or have drinks after work with male executives. The women avoided attending corporate social gatherings unless they had to attend.

Having large families and having been kept apart from other races during apartheid, the women had not mastered the skills of networking with other race groups and especially not with males. They indicated that their best friends were their sisters, cousins or women in their communities. Sushmita, a human resource director, voiced her lack of desire to advance her career through networking:

Why should I advance my career through networking? The quality of my work should speak for itself. Merit should be the only criterion through which people should be promoted. Now I know of males who are duds but are promoted because they are buddies with the CEO.

All the women also refused to play political games in order to further their careers. Having been raised in the Indian culture, which emphasises ethical behaviour and integrity, the participants believed that advancing their careers through such means went against their value systems. Zeenat pointed out that women did not desire to engage in political games to advance their careers:

Playing political games and getting promoted does not mean that you are ready for the next step on the career ladder. I have noticed men and women who do not have the know-how of managing people get promoted. They do not earn the respect of employees and soon they are caught out for not knowing their work. I have been raised to do my job with integrity and not to use devious means of moving up the corporate ladder.

\section{"Normality" at Home}

The majority of the participants indicated that in their homes and the Indian community they reverted to being passive, respecting their elders, allowing males to handle conflict outside their homes and upholding sex segregation at social functions. Although they had power and authority in the workplace, they were reluctant to challenge the authority of their husbands and fathers because such behaviour by Indian women was frowned upon by family and community members. The women found that adjusting to being subjugated in the home and community led to inner conflict and turmoil as they had to resist the temptation to be outspoken and handle conflict that arose.

The women also expressed a desire to talk to male family friends about business instead of talking to women about cooking and children, but they were 
not allowed to do so. Exposure to Western norms in the workplace changed these women' cultural values over time, but they tried to live up to the expectations of their families and communities. Therefore the women felt they were operating in a liminal space: not only did they feel like aliens in their own homes and communities but they also felt like strangers in the corporate environment where they were not fully accepted. Bipasha, an operations manager, referred to the difficulty of switching personas between home and the workplace, a sentiment that the other women echoed:

I feel like I'm behind a mask. At home I'm the epitome of a respectable Indian mother, daughter and sister who allows men to lead in the home and in society. At work I'm an executive who is in charge and who commands respect. It's a schizophrenic life that I lead and I find it difficult to be the obedient woman in the home, especially now that I have advanced to such an extent in my career.

The married women admitted that they still adhered to the traditional gender roles prescribed within the Indian culture according which wives had to be subservient and give priority to their husbands' professions. Although their decision to place their husbands' careers before their own led to their unhappiness, their families expected them to do that and it formed part of their cultural values. Waheeda's words reflected the attitudes of the other married participants towards their husbands' professions:

We have shared our career dreams with each other, but I will give up my job in order to promote him. As an Indian female my household duties take precedence and his job takes precedence, as is the traditional expectation.

The participants' comments quoted above indicate the extent to which they engaged in hybrid identity work.

\section{Conclusion}

The study reported on in this paper explored the extent to which racio-ethnic minority women engaged in identity work and formed hybrid identities in their upward career mobility.

The minimal literature on hybrid identity work of minorities in organisations is confined to studies involving first- and second-generation migrants. 
In contrast, this study focused on fourth- and fifth-generation South African settlers (Van Laer and Janssens 2008). The participants possessed some hybrid identities, such as having a command of the English language (which is regarded as the language used in business) and wearing Western attire. Their hybrid identity work was circumscribed as a result of living in isolation in Indian townships away from other racial groups - a legacy of apartheid.

Within the workplace, the hybrid identity work the women engaged in stemmed from being selective as to the types of managerial traits they were prepared to include in their self-concepts. Pieterse (2001) points out that hybrid identities in Asian cultures are not forced but are readily accepted. This statement contradicts the findings of this study: according to the women, it was "inscribed" on them what it meant to be a manager and they were made to understand that rejecting a "managerial identity" and negating certain behaviours would hamper their upward career mobility. For this reason the women consciously chose to embrace certain male managerial traits that would enable them to progress in their careers. Adopting these characteristics went against the respondents' cultural notions of what it meant to be an Indian woman and caused them to experience tremendous inner conflict regarding their identity and self-concept, yet the women regarded these behaviours as essential to their career advancement. They therefore "mimicked", albeit to a limited extent, the behaviours of their white male counterparts who were in charge of management (Bhabha 1994).

There were certain elements of the organisational culture that the participants refused to embrace or negotiate owing to their strong ethnic beliefs. Ashforth, Kreiner, and Fugate (2000) point out that ethnic culture influences the extent to which one integrates a role or transitions to another role. An individual's culture influences both self-concept and workplace behaviour and roles. Culture played a major role in whether the participants would transform to total hybrid identities in the workplace or not. The women had strong cultural values and these had been reinforced by apartheid which forced them to live among a community of Indians and have minimal contact with other racial groups. These Indian women's behaviour was monitored by family and community members and they were reprimanded if they did not toe the line. By implication, the women's movements in the workplace were monitored by the Indian males they worked with, and the participants had to ensure that while they integrated some archetypal managerial traits they had to draw the line at others.

The fact that these women still lived in Indian townships meant that they had to maintain their respectability in the family and community to save face. The fear of losing their respectability resulted in a strong adherence to certain 
cultural values, as was demonstrated by the women's refusal to join the "old boys" club to advance their careers. In this way they maintained the essential notions of what it means to be a respectable Indian woman. They were socialised to be respectable women as the honour and the integrity of a family depend on the behaviour of the females in the home (Mir 2009).

The integration of multiple, shifting identities to conform to organisational culture becomes burdensome and not emancipatory (Sirin and Fine 2008). The participants were fortunate enough to be spared having to fully adhere to organizational culture because they were protected by legislation such as the Employment Equity Act of 1998 (South Africa 1998), which promotes previously disadvantaged individuals like themselves. Legislation supported them in advancing their career without having to fully negate their cultural identities.

Interestingly, the women started experiencing conflict relating to their ethnic identities when they were in their home environments. Having to formulate "different" (workplace) identities that did not resonate with their cultural values and beliefs the women were caught in a liminal or third space. They had moved beyond the gender prescriptions of being an Indian woman but at the same time they did not entirely belong in the workplace. This situation caused the women to experience tension and display paradoxical behaviour. The finding of the study regarding participants' behaviour resonates with reports in the literature that hybrid identity work results in minority individuals negotiating their identities up to a level they are comfortable with (Friedman 1999; Van Laer and Janssens 2008). The women are forced to identify not only with their cultural roles at home and in the community but also (albeit to a lesser extent) with their managerial roles in the workplace. As a result they tend to revert to being "ideal" wives and mothers in their home environments although this causes them to experience tremendous inner turmoil (Ashforth, Kreiner, and Fugate 2000).

\section{References}

Alvesson, M., and H. Willmott. 2002. "Identity Regulation as Organizational Control: Producing the Appropriate Individual." Journal of Management Studies 39 (5): 619644. https://doi.org/10.1111/1467-6486.00305.

Andersson, T. 2010. "Struggles of Managerial Being and Becoming. Experiences from Managers' Personal Development Training." Journal of Management Development 29 (2): 167-176. https://doi.org/10.1108/02621711011019305. 
Andrews, P. E. 2001. "From Gender Apartheid to Non-Sexism: The Pursuit of Women's Rights in South Africa." North Carolina Journal of International Law and Commercial Regulation 26 (3): 1-23.

Antecol, H., and K. Bedard. 2002. "The Relative Earnings of Young Mexican, Black and White Women." Industrial and Labor Relations Review 56 (1):122-135.

Ashforth, B. E. 2001. Role Transitions in Organizational Life: An Identity-Based Perspective. Mahwah, NJ: Erlbaum.

Ashforth, B. E., G. E. Kreiner, and M. Fugate. 200o. "All in a Day's Work: Boundaries and Micro Role Transitions." Academy of Management Review 25 (3): 472-491. https:// doi.org/10.5465/AMR.2000.3363315.

Atewologun, D., and V. Singh. 2010. "Challenging Ethnic and Gender Identities. An Exploration of UK Black Professionals' Identity Construction.” Equality, Diversity and Inclusion: An International Journal 29 (4): 332-347. https://doi.org/ 10.1108/02610151011042394.

Bazylevych, M. Y. 2010. "Negotiating New Roles, New Moralities: Ukrainian Women Physicians at a Post-Socialist Crossroad." PhD thesis, State University of New York at Albany, New York, NY.

Beech, N. 2008. "On the Nature of Dialogic Identity Work." Organization 15 (1): 51-74. https://doi.org/10.1177/1350508407084485.

Benton, L., and J. Muth 2000. "On Cultural Hybridity: Interpreting Colonial Authority and Performance." Journal of Colonialism and Colonial History 1 (1): 1-24.

Bhabha, H. 1994. The Location of Culture. New York: Routledge.

Blenkinsopp, J., and B. Stalker. 2004. "Identity Work in the Transition from Manager to Management Academic." Management Decision 42 (3/4): 418-429. https://doi. org/10.1108/00251740410518903.

Booysen, L. 2007. "Barriers to Employment Equity Implementation and Retention of Blacks in Management in South Africa." South African Journal of Labour Relations $31(1): 47-71$.

Brettell, C. B., and F. Nibbs. 2009. "Lived Hybridity: Second-Generation Identity Construction through College Festival." Identities: Global Studies in Culture and Power 16:678-699. https://doi.org/10.1080/10702890903307142.

Carrim, NMH. 2012. '“Who am I?"-South African Indian women managers' struggle for identity: escaping the ubiquitous cage." PhD dissertation. University of Pretoria: Pretoria.

Charmaz, K. 2006. Constructing Grounded Theory. A Practical Guide through Qualitative Analysis. London: Sage.

Cieslik, A., and M. Verkuyten. 2006. "National, Ethnic and Religious Identities: Hybridity and the Case of the Polish Tatars." National Identities 8 (2): 77-93. http:// dx.doi.org/10.1080/14608940600703650. 
Clark, T., and G. Salaman. 1998. “Telling Tales: Management Gurus' Narratives and the Construction of Managerial Identity." Journal of Management Studies 35 (2): 137-161. https://doi.org/10.1111/1467-6486.00088.

Cox, T., Jr. 1990. "Problems with Research by Organizational Scholars on Issues of Race and Ethnicity." Journal of Applied Behavioral Science 26 (1): 5-23. https://doi.org/10.1 177\%2Foo2188639002600103.

Daniel, J., A. Habib, and R. Southall. 2003. State of the Nation. South Africa 2003-2004. Cape Town: HSRc Press.

Darling-Wolf, F. 2008. "Disturbingly Hybrid or Distressingly Patriarchal? Gender Hybridity in a Global Environment." In Hybrid Identities. Theoretical and Empirical Examinations, edited by K. I. Smith, and P. Leavy, 63-91. Leiden, The Netherlands: Koninklijke Brill NV.

Das, D. 2007. "Globalization and the Theatre of Work: Exploring Identity Dynamics in Indian International Call Centers." PhD thesis, Graduate School of Syracuse University, Syracuse.

Dennis, M. R, and A. Kunkel. 2004. "Perceptions of men, women, and CEOs: The effects of gender identity." Social Behavior and Personality: an international journal 32 (2): $155^{-171 .}$

Early, P. C., and E. Mosakowski. 200o. "Creating Hybrid Team Cultures: An Empirical Test of Transnational Team Functioning." Academy of Management Journal 43 (1): 26-49. https://doi.org/10.2307/1556384.

Easthope, H. 2009. "Fixed Identities in a Mobile World? The Relationship between Mobility, Place and Identity." Identities: Global Studies in Culture and Power 16 (1): 61-82. http://dx.doi.org/10.1080/10702890802605810.

Essers, C., and Y. Benschop. 2009. "Muslim Businesswomen Doing Boundary Work: The Negotiation of Islam, Gender and Ethnicity within Entrepreneurial Contexts." Human Relations 62 (3): 403-423. https://doi.org/10.1177/0018726708101042.

Ezzel, M. B. 2009. "'Barbie Dolls' on the Pitch: Identity Work, Defensive Othering, and Inequality in Women's Rugby." Social Problems 56 (1): 111-131. https://doi.org/10.1525/ sp.2009.56.1.111.

Fearfull, A., and N. Kamenou. 2006. "How do You Account for It? A Critical Exploration of Career Opportunities for and Experiences of Ethnic Minority Women." Critical Perspectives on Accounting 17 (7): 883-901. https://doi.org/10.1016/j. cpa.2005.08.006.

Fitzgerald, S. A. 2007. "Hybrid Identities in Canada's Red River Colony." The Canadian Geographer $5^{1}$ (2): 186-201. https://doi.org/10.1111/j.1541-0064.2007.00173.x.

Ford, J. 2006. "Discourses of Leadership: Gender, Identity and Contradiction in a UK Public Sector Organization.” Leadership 2 (1): 77-99. https://doi.org/10.1177/ 1742715006060654 . 
Friedman, J. 1999. "The Hybridization of the Roots and the Abhorrence of the Bush." In Spaces of Culture: City-Nation-World, edited by M. Featherstone, and S. Lash, 230-250. London: Sage.

Giscombe, K., and M. C. Mattis. 2002. "Leveling the Playing Field for Women of Color in Corporate Management: Is the Business Case Enough?" Journal of Business Ethics 37 (1): 103-119. https://doi.org/10.1023/A:1014786313354.

Greeff, A., and P. Nel. 2003. "Employment Transformation Enhancement in South Africa: Establishing a Job-Sharing Model to Promote Employment Equity." South African Journal of Labour Relations (Winter): 23-62.

Helms, J. 1990. "A Model of White Racial Identity Development." In Black and White Racial Identity: Theory, Research and Practice, edited by J. Helms, 49-66. Westport, ст: Greenwood.

Hogg, M. A., D. J. Terry., and K. M. White. 1995. "A Tale of Two Theories: A Critical Comparison of Identity Theory with Social Identity Theory." Social Psychology Quarterly 58 (4): 255-269.

Ibarra, H. 2005. Identity Transitions: Possible Selves, Liminality and the Dynamics of Career Change. Faculty and Research Working Paper no. 51/OB, INSEAD, France.

Ibarra, H., and R. Barbulescu. 2010. "Identity as Narrative: Prevalence, Effectiveness, and Consequences of Narrative Identity Work in Macro Work Role Transitions." Academy of Management Review 35 (1): 135-154. https://doi.org/10.5465/AMR.2010.45577925.

Ibarra, H., and J. L. Petriglieri. 2010. "Identity Work and Play." Journal of Organizational Change Management 23 (1): 10-25. https://doi.org/10.1108/09534811011017180.

Jenkins, R. 1996. Social Identity. London, U K: Routledge.

Kärreman, D., and M. Alvesson. 2004. "Cages in Tandem: Management Control, Social Identity, and Identification in a Knowledge-Intensive Firm." Organization 11 (1): 149175. http://dx.doi.org/10.1177/1350508404039662.

Kreiner, G., E. Hollensbe, and M. Sheep. 2006. "Where is the 'Me' among the 'We'? Identity Work and the Search for Optimal Balance." Academy of Management Journal 49 (5): 1031-1057. https://doi.org/10.5465/AMJ.2006.22798186.

Ladge, J. J., J. A. Clair, and D. Greenberg. 2012. "Cross-Domain Identity Transition during Liminal Periods: Constructing Multiple Selves as Professional and Mother during Pregnancy." Academy of Management Journal 55 (6): 1449-1471. https://doi. org/10.5465/amj.2010.0538.

Luk-Fong, P. Y. Y. 2010. "Towards a Hybrid Conceptualisation of Chinese Women Primary School Teachers' Changing Femininities - A Case Study of Hong Kong." Gender and Education 22 (1): 73-86. https://doi.org/10.1080/09540250802581834.

Mathur-Helm, B. 2004. "Women in Management in South Africa." In Women in Management Worldwide, edited by M. J. Davidson, and R. J. Burke, 329-342. Hampshire, uk: Ashgate. 
Mathur-Helm, B. 2005. "Equal Opportunity and Affirmative Action for South African Women: A Benefit or Barrier?” Women in Management Review 20 (1): 56-71. http:// doi.org/10.1108/09649420510579577.

McKinley, E. 2008. "From Object to Subject: Hybrid Identities of Indigenous Women in Science." Cultural Studies of Science Education 3 (4): 959-975. https://doi.org/10.1007/ s11422-008-9128-7.

Mehrotra, M., and T. M. Calasanti. 2010. "The Family as a Site for Gendered Ethnic Identity Work among Asian Indian Immigrants." Journal of Family Issues 31 (6): 778807. https://doi.org/10.1177/0192513Xo9357557.

Merriam-Webster. n.d. s.v. "hybrid (n)". Accessed 09 28, 2017. http://www.merriam-webster.com/dictionary/hybrid.

Mir, S. 2009. "Not Too 'College-Like', Not Too Normal: American Muslim Undergraduate Women's Gendered Discourses." Anthropology and Education Quarterly 40 (3): 237256. http://doi.org/10.1111/j.1548-1492.2009.01043.x.

Moosa, N. 2004. Unveiling the Mind: A Herstory of the Historical Evolution of the Legal Position of Women in Islam. Cape Town: Mills Litho.

Naidoo, V., and M. Kongolo. 2004. "Has Affirmative Action Reached South African Women?" Journal of International Women's Studies 6 (1): 124-136.

Pieterse, J. N. 2001. "Hybridity, So What? The Anti-Hybridity Backlash and the Riddles of Recognition." Theory, Culture and Society 18 (2-3): 219-245.

Ramsay, E. 2007. "Between Non-Racialism and Multiculturalism: Indian Identity and Nation Building in South Africa." Economische en Sociale Geografie 98 (4): 468-481. https://doi.org/10.1111/j.1467-9663.2007.00415.x.

Ritchie, J., and J. Lewis. 2003. Qualitative Research Practice. A Guide for Social Science Students and Researchers. London: Sage.

Sirin, S. R., and S. Fine. 2008. Muslim American Youth: Understanding Hyphenated Identities through Multiple Methods. New York, NY: New York University Press.

South Africa. 1998. Employment Equity Act, No 55 of 1998. Accessed March 1, 2016. www .hpcsa.co.za/hpcsa/.../EMPLOYMENT\%2oEQUITY\%20ACT.pdf.

Stoker, J. I., M. van der Velde, and J. Lammers. 2012. "Factors Relating to Managerial Stereotypes: The Role of Gender of the Employee and the Manager and Management Gender Ratio." Journal of Business Psychology 27 (1): 31-42. https://doi.org/10.1007/ s10869-011-9210-0.

Strauss, A. L., and J. Corbin. 1998. Basics of Qualitative Research. Techniques and Procedures for Developing Grounded Theory. 2nd ed. London: Sage.

Sturdy, A., M. Brocklehurst, D. Winstanley, and M. Littlejohns. 2006. "Management as a (Self) Confidence Trick: Management Ideas, Education and Identity Work." Organization 13 (6): 841-86o. https://doi.org/10.1177/1350508406068501. 
Sveningsson, S., and M.Alvesson. 2003. "Managing Managerial Identities: Organizational Fragmentation, Discourse and Identity Struggle." Human Relations 56 (10): 1163-1193. http://dx.doi.org/10.1177/00187267035610001.

Tajfel, H. 1972. "La cate'gorization sociale." In Introduction a' la Psychologie sociale, edited by S. Moscovici, 272-302. Paris: Larousse.

Van Laer, K., and M. Janssens, M. 2008. "The Workplace Experiences of SecondGeneration Minority Professionals: Upsetting Practices and Hybrid Identity Work." In Proceedings of the Critical Management Studies Research Workshop on Stream: Critical Gender and Diversity Issues in Management and Organization Theory, edited by [insert the initial and surname of the editor]. Anaheim, CA, August 7-8.

Watson, T. J. 2008. "Managing Identity: Identity Work, Personal Predicaments and Structural Circumstances." Organization 15 (1): 121-143. https://doi.org/10.1177 /1350508407084488.

Watson, T. J. 2009. "Narrative, Life Story and Manager Identity: A Case Study in Autobiographical Identity Work." Human Relations 62 (3): 425-452.

Wickham, M., and M. Woods. 2005. "Reflecting on the Strategic Use of CAQDAS to Manage and Report on the Qualitative Research Report." The Qualitative Report 10 (4): 687-702. 